$\xi^{2}=-1$

\title{
Spatial Assessment of Groundwater Quality with Special Reference to Nitrate Pollution in Raipur City, Chhattisgarh State, India using Geographical Information System
}

\author{
Rubia Khan, D.C. Jhariya* \\ National Institute of Technology Raipur, G.E. Road, Raipur, Chhattisgarh, India \\ *Corresponding author E-mail: dcjhariya.geo@nitrr.ac.in
}

\begin{abstract}
Groundwater quality is one of the most important aspects for sustainable development of social and economic life. In present study, 41 groundwater samples were collected systematically during the pre-monsoon (May 2015) and post-monsoon (December 2015) periods. Nine parameters, i.e. $\mathrm{EC}, \mathrm{Ca}, \mathrm{Mg}, \mathrm{Na}, \mathrm{K}, \mathrm{NO} 3, \mathrm{SO}_{4}, \mathrm{HCO}_{3}$ and $\mathrm{Cl}$ were analyzed in the laboratory adapting a standard protocol of APHA, 1995. The analyzed samples were compared with BIS and WHO standard for drinking purpose and spatial distribution map was prepared using Arc GIS Software. In present study, it is found that $\mathrm{Ca}, \mathrm{Mg}, \mathrm{K}$ and $\mathrm{NO}_{3}$ are above permissible limit and $\mathrm{SO} 4$ is above an acceptable limits according to BIS standard. Present study reflecting that main causes of groundwater pollution in study area are anthropogenic activities.
\end{abstract}

Keywords: Groundwater Quality; Groundwater Pollution; Groundwater; Raipur City; Chhattisgarh.

\section{Introduction}

Groundwater is very essential need for sustainable life on earth surface. Quality of groundwater, to large extent, depends on geogenic as well as anthropogenic activity. There are many causes, which pollute the groundwater varying from septic tanks to industries. Groundwater pollution is difficult to detect and control. Thus, once it is polluted, it is very difficult to rehabilitate its quality. It is estimated that around 37.7 million Indians are affected by waterborne diseases every year, 1.5 million children are estimated to die of diarrhea alone, and 73 million working days are lost due to waterborne disease each year (Khandare 2013).

Contamination of groundwater by nitrate is considered a global problem (Abdulrahman et al. 2009, Jhariya et al. 2012). Nitrate pollution is a rising concern throughout the world that has been regulated through the introduction of several legislations or directives in different countries (Angelopoulos et al. 2008). Nitrates introduced in the groundwater from a variety of sources like agricultural activities, poor sewer system, wastewaters, and industrial activities (Abdulrahman et al. 2009). Nitrate is the most frequently introduced pollutant into the groundwater system (Spalding \& Exner 1993, Angelopoulos et al. 2008). Agricultural activities, especially cultivation and fertilization, are principal causes of nitrate contamination on a regional scale and also from poorly treated or untreated human and animal wastes (Hudak 2000, Nolan 2001, Abdulrahman et al. 2009). Nitrate is also a by-product of many industrial processes, including paper and munitions manufacturing industries (Elmidaoui et al. 2001, Abdulrahman et al. 2009). Nitrate is also.

Very mobile in groundwater and tends not to adsorb or precipitate on aquifer solids (Hem 1985, Abdulrahman et al. 2009, Imran 2009, Imran et al. 2010). The adverse health effects of high nitrate levels in drinking water are well documented (Fan et al. 1987,
Ward et al. 1994, Fan and Steinberg 1996, Abdulrahman et al. 2009). As per the BIS Standard for drinking water, the maximum desirable limit of Nitrate concentration in ground water is $45 \mathrm{mg} / \mathrm{l}$ with no relaxation (BIS, 1991).

Raipur city is rapidly growing as a result of increase in industrialization and urbanization (Agarwal et al. 2013). The demand of water is increasing, which leads to its overexploitation causing depletion of quantity and deterioration of quality of groundwater. At the same time, Wastes generated from a wide variety of Industries, agricultural and domestic activities. These wastes are dumped into pits, low-lying areas around the city, constituents of which percolates and pollute groundwater. Due to Karstified nature of geologic formation, the groundwater of study area is highly susceptible to pollution. In present paper, groundwater pollution due to anthropogenic activities of Raipur city is studied.

\section{Study area}

Raipur city is Divisional and District Headquarter, and it is culturally, educationally and economically forward town in the state of Chhattisgarh. Raipur city is situated in western part of Raipur district, Chhattisgarh, India. Study area falls longitude between $81^{\circ} 35^{\prime}$ to $81^{\circ} 40^{\prime}$ and latitudes between $21^{\circ} 10^{\prime}$ to $21^{\circ} 20^{\prime}$ under Survey of India (SOI) toposheet no. 64G/11 and 64G/12. Present study area encompassing a geographical area of approximately $150 \mathrm{~km}^{2}$ covering part of Raipur block of Raipur districts. Location map and groundwater sample location map of the study area is given in Fig. 1.

Raipur has a tropical wet and dry climate, Temperatures remain moderate throughout the year, except March to June, which can be extremely hot. The temperature in April to May sometimes rises above $48{ }^{\circ} \mathrm{C}\left(118{ }^{\circ} \mathrm{F}\right)$. These summer months also have dry and hot winds. In summers, the temperature can also go up to $50{ }^{\circ} \mathrm{C}$. 
The city receives about $1,300 \mathrm{~mm}$ of rainfall, mostly in the monsoon season from late June to early October. Winters last from
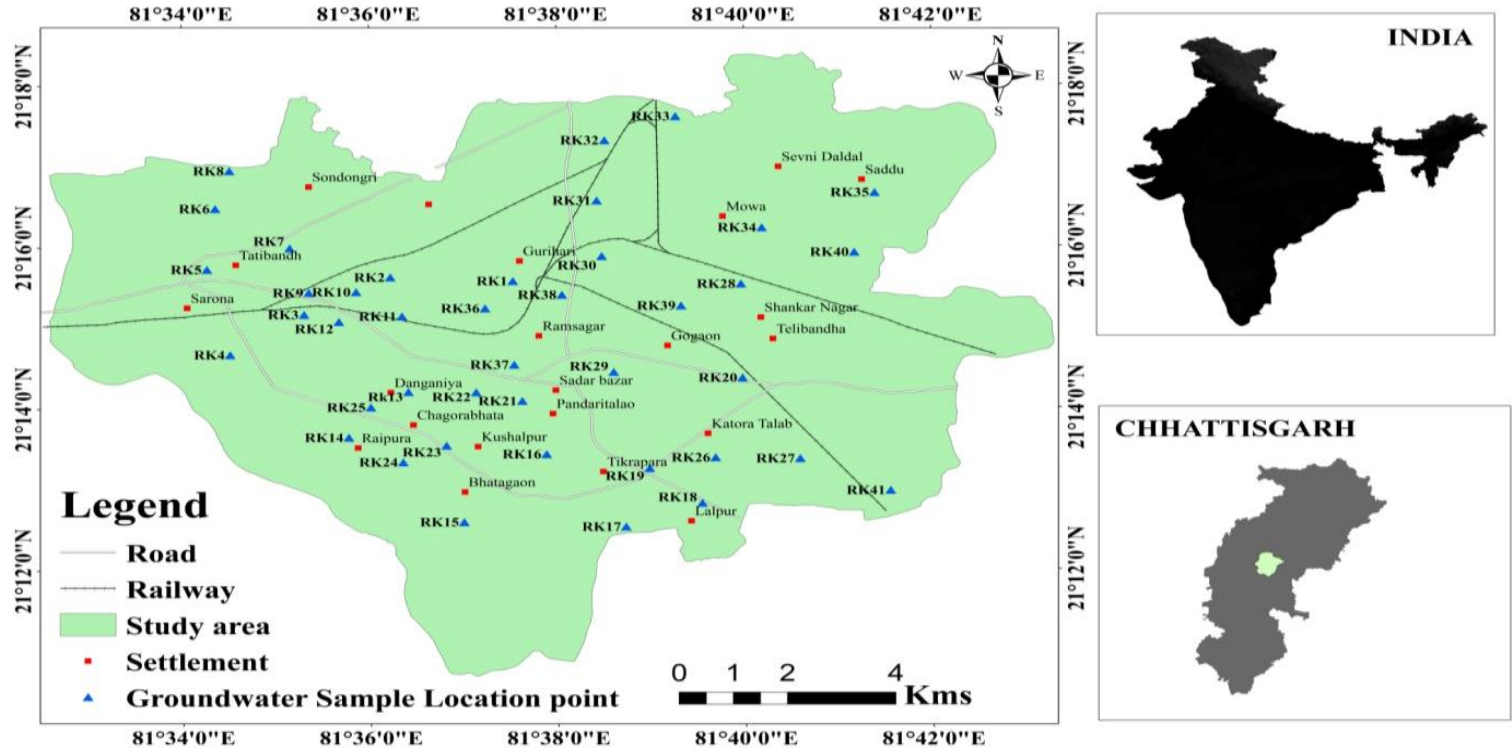

\section{Methodology}

\subsection{Collection of groundwater samples}

A total 41 groundwater samples were collected from study area during pre-monsoon (May 2015) and post-monsoon (December 2015) periods from different location of study area. Prior to collection of water samples the bottles were thoroughly washed with distilled water in the laboratory. The bottles were rinsed to avoid any possible contamination and every precautionary measure was taken. Methods of collection and analysis of water samples was adopted using standard protocols (APHA, 1995). Then, the samples were sealed, numbered, and were carefully taken to the laboratory for the chemical analysis. Locations of samples were collected using Global Positioning System (GPS).

\subsection{Laboratory analysis of groundwater samples}

In the present study nine parameters are analyzed viz. $\mathrm{EC}, \mathrm{Ca}, \mathrm{Mg}$ $\mathrm{Na}, \mathrm{K}, \mathrm{HCO}_{3}, \mathrm{NO}_{3}, \mathrm{SO}_{4}$ and $\mathrm{Cl}$. The samples were analyzed in Laboratory of Chhattisgarh Council of Science and Technology (CGCOST), Raipur using standard protocol of APHA (1995). Methods for analysis of parameter are given in Table 1 .
Table 1: Methods for Analysis of Parameter

\begin{tabular}{ll}
\hline Parameter & Method \\
\hline $\mathrm{EC}($ Electrical conductivity, & EC meter \\
$\mu \mathrm{s} / \mathrm{cm})$ & EDTA Titration \\
$\mathrm{Ca}($ Calcium, $\mathrm{mg} / \mathrm{l})$ & Atomic Absorption Spectroscopy \\
$\mathrm{Mg}($ Magnesium, mg/l) & (AAS) \\
$\mathrm{Na}($ Sodium, $\mathrm{mg} / \mathrm{l})$ & Flame Photometer \\
$\mathrm{K}($ Potassium, mg/l) & Flame Photometer \\
$\mathrm{HCO}_{3}($ Bicarbonate, $\mathrm{mg} / \mathrm{l})$ & Titration method \\
$\mathrm{NO}_{3}($ Nitrate, $\mathrm{mg} / \mathrm{l})$ & UV-vis Spectroscopy \\
$\mathrm{SO}_{4}($ Sulphate, $\mathrm{mg} / \mathrm{l})$ & UV-vis Spectroscopy \\
$\mathrm{Cl}_{(\text {Chloride }, \mathrm{mg} / \mathrm{l})}$ & Titration method \\
\hline
\end{tabular}

\subsection{Groundwater samples analysis}

The major drinking water quality parameters along with corresponding permissible limits as per Bureau of Indian Standards (BIS 2003) and its statistics is given in Table 2.

\subsection{Geographical Information System (GIS) based analysis}

The GIS based analysis of spatial behavior of the groundwater quality in the study area was done using spatial analyst module of Arc GIS 9.3. The Inverse Distance Weighted (IDW) method interpolation techniques was used in the analysis in GIS environment.

Table 2: Statistics of Groundwater Samples and Drinking Water Comparison with Water Quality Standard (BIS, 1991)

\begin{tabular}{|c|c|c|c|c|c|c|c|c|c|c|}
\hline \multirow{2}{*}{ Parameters } & \multicolumn{2}{|l|}{ Minimum } & \multicolumn{2}{|l|}{ Maximum } & \multicolumn{2}{|l|}{ Median } & \multicolumn{2}{|l|}{ SD } & \multicolumn{2}{|c|}{$\begin{array}{l}\text { Drinking } \\
\text { Standard }\end{array}$} \\
\hline & $\begin{array}{l}\text { Pre- } \\
\text { monsoon }\end{array}$ & $\begin{array}{l}\text { Post- mon- } \\
\text { soon }\end{array}$ & $\begin{array}{l}\text { Pre- mon- } \\
\text { soon }\end{array}$ & $\begin{array}{l}\text { Post- mon- } \\
\text { soon }\end{array}$ & $\begin{array}{l}\text { Pre- mon- } \\
\text { soon }\end{array}$ & $\begin{array}{l}\text { Post- mon- } \\
\text { soon }\end{array}$ & $\begin{array}{l}\text { Pre- mon- } \\
\text { soon }\end{array}$ & $\begin{array}{l}\text { Post- mon- } \\
\text { soon }\end{array}$ & $\mathrm{AL}$ & PL \\
\hline $\mathrm{EC}$ & 535 & 636 & 1368 & 1592 & 803 & 1092 & 182.30 & 233.62 & - & - \\
\hline $\mathrm{Ca}$ & 47.4 & 12.76 & 260.60 & 205.81 & 137.851 & 114.903 & 44.51 & 40.03 & 75 & 200 \\
\hline $\mathrm{Mg}$ & 4.3 & 6.04 & 62.62 & 82.49 & 28.675 & 26.4 & 14.51 & 20.09 & 30 & - \\
\hline $\mathrm{Na}$ & 15.6 & 18.8 & 234 & 159 & 76.9 & 47.8 & 39.42 & 36.56 & $50 *$ & $200^{*}$ \\
\hline $\mathrm{K}$ & 0.04 & 0.11 & 65.5 & 196.3 & 7.2 & 2.6 & 17.34 & 35.81 & $10 *$ & $12 *$ \\
\hline $\mathrm{NO}_{3}$ & 0 & 0 & 120.15 & 150.26 & 20 & 26.0843 & 25.03 & 32.611 & 45 & NR \\
\hline $\mathrm{SO}_{4}$ & 14.5 & 1.2 & 320.15 & 280.31 & 102.11 & 95.3 & 67.91 & 61.03 & 200 & 400 \\
\hline $\mathrm{Cl}$ & 40 & 50 & 270 & 260 & 140 & 150 & 59.11 & 42.03 & 250 & 1000 \\
\hline
\end{tabular}

*WHO standards (BIS standards are not available). 


\section{Result \& discussion}

\subsection{Spatial analysis}

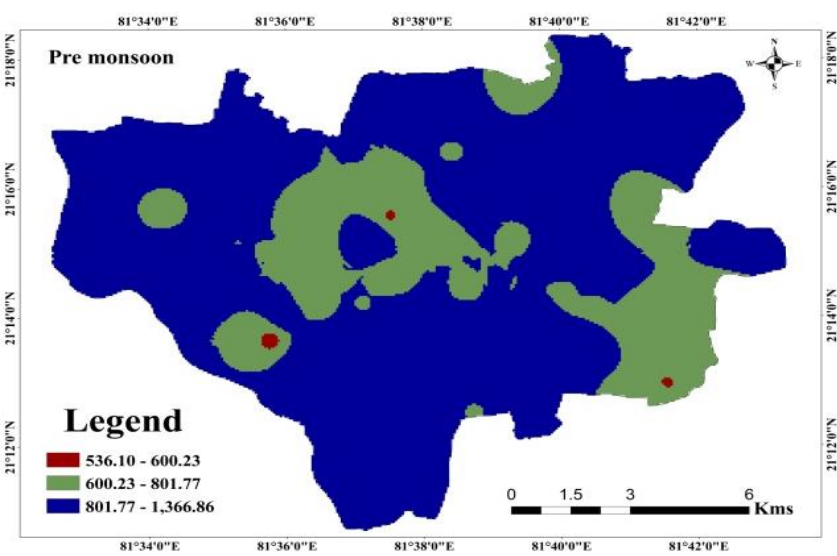

Fig. 2a:Spatial Distribution Map of EC.
EC: The spatial analysis for two seasons i.e. pre-monsoon and post monsoon is given in Fig. 2 a \& b. During pre-monsoon seasons EC is varying from $1368 \mu \mathrm{s} / \mathrm{cm}$ to 535.001 and during postmonsoon season it is varying from $1592 \mu \mathrm{s} / \mathrm{cm}$ to $636.001 \mu \mathrm{s} / \mathrm{cm}$.

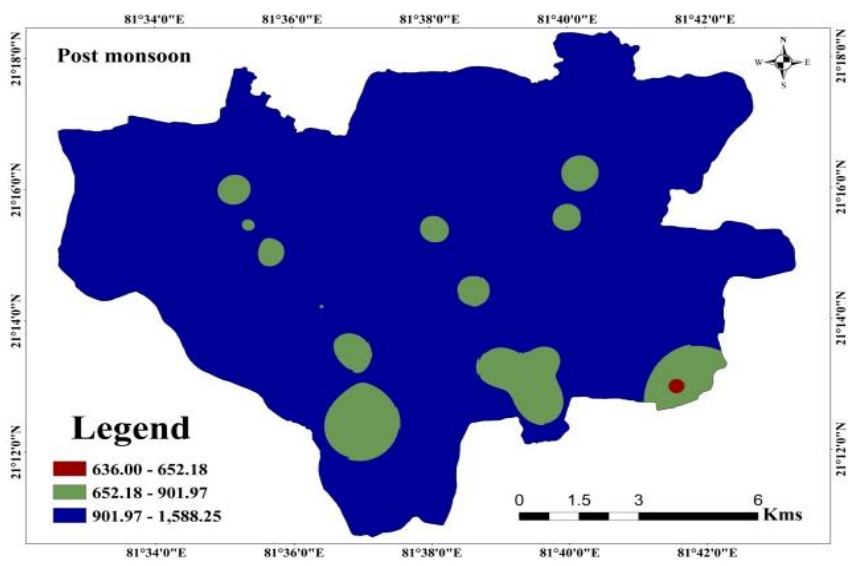

Fig. 2b: Spatial Distribution Map of EC

Ca: The spatial analysis for two seasons i.e. pre-monsoon and post-monsoon is given in Fig. 3 a \& b. During pre-monsoon seasons Ca is varying from $260.603 \mathrm{mg} / \mathrm{l}$ to $47.40 \mathrm{mg} / \mathrm{l}$ whereas during post-monsoon periods it is varying from $205 \mathrm{mg} / \mathrm{l}$ to $12.76 \mathrm{mg} / \mathrm{l}$

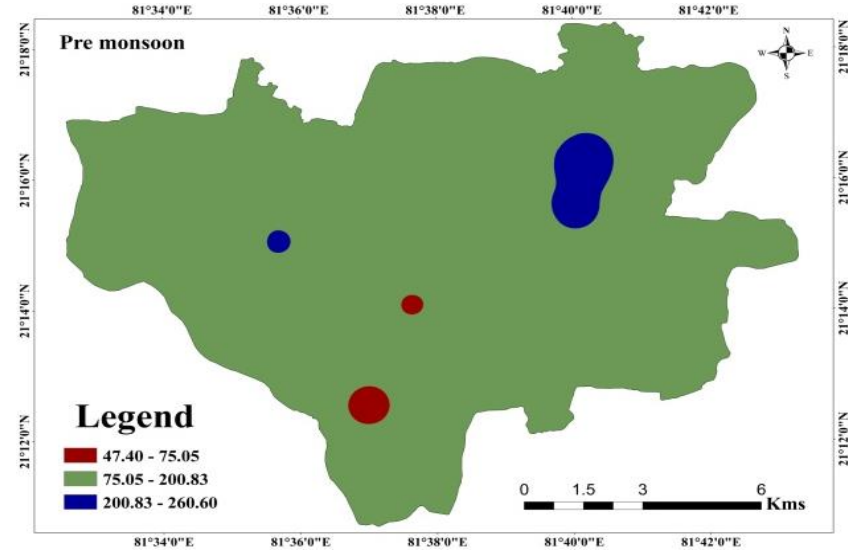

Fig. 3a: Spatial Distribution Map of Ca.

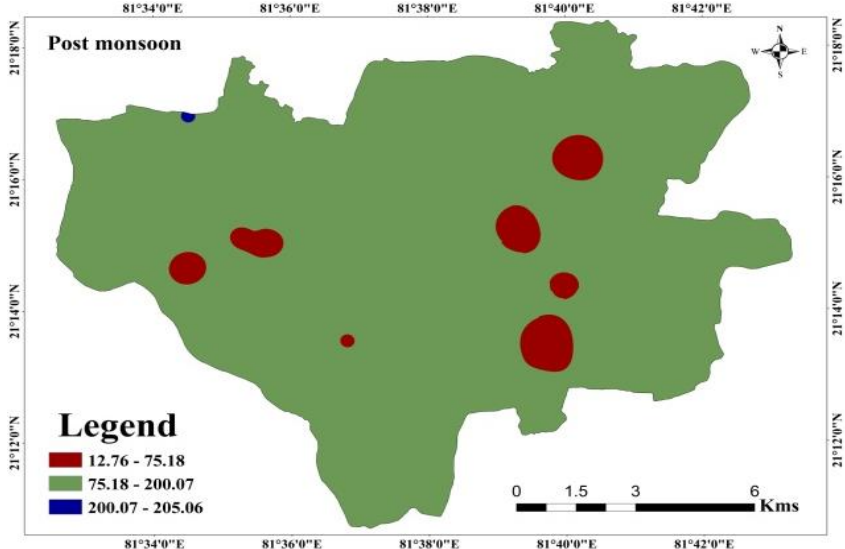

Fig. 3b: Spatial Distribution Map of Ca.

$\mathrm{Mg}$ : The spatial analysis for two seasons i.e. pre-monsoon and post monsoon is given in Fig. 4 a \& b. During pre-monsoon seasons Mg is varying from $62.62 \mathrm{mg} / \mathrm{l}$ to $4.39 \mathrm{mg} / \mathrm{l}$ and in post monsoon season it is varying from $82.49 \mathrm{mg} / \mathrm{l}$ to $6.04 \mathrm{mg} / \mathrm{l}$.

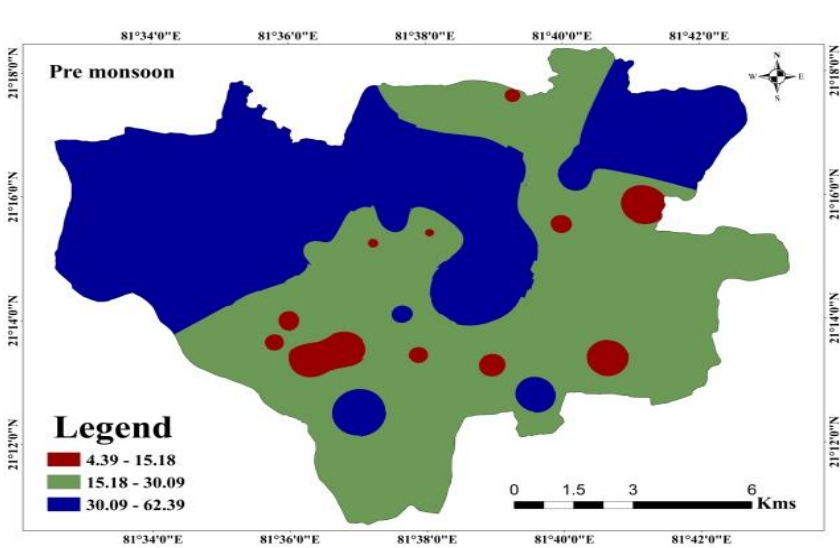

Fig. 4a: Spatial Distribution Map of Mg.

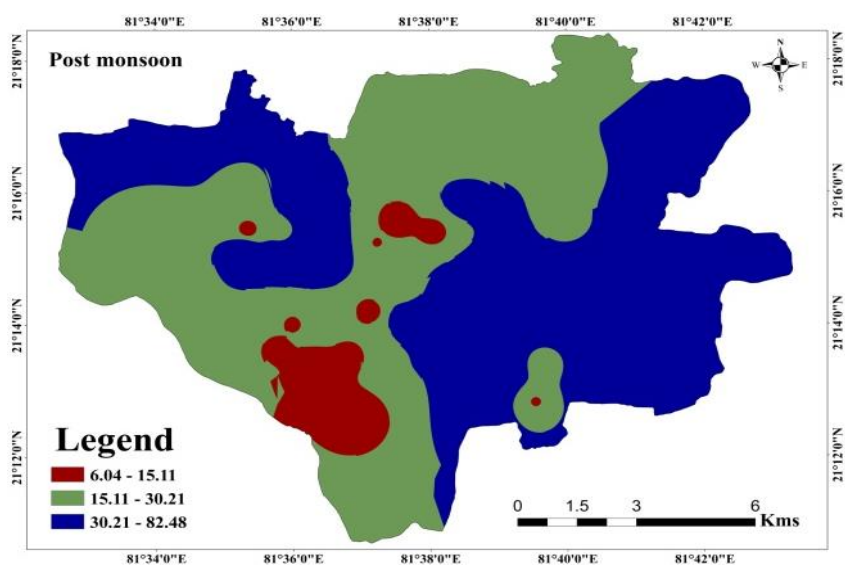

Fig. 4b: Spatial Distribution Map of Mg.

Na: The spatial analysis for two seasons i.e. pre-monsoon and post monsoon is given in Fig. 5 a \& b. During pre-monsoon seasons Na is varying from 233 $\mathrm{mg} / \mathrm{l}$ to $15.60 \mathrm{mg} / \mathrm{l}$ and in post monsoon season it is varying from $158.99 \mathrm{mg} / \mathrm{l}$ to $18.00 \mathrm{mg} / \mathrm{l}$. 


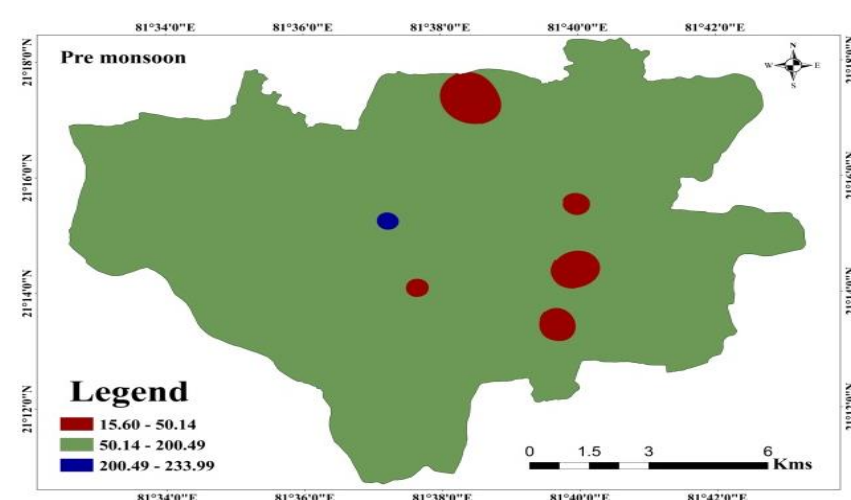

Fig. 5a: Spatial Distribution Map of Na.

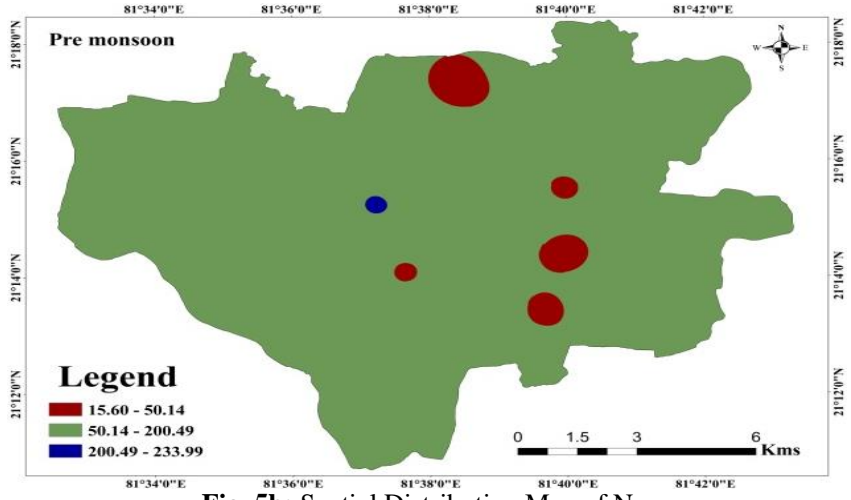

Fig. 5b: Spatial Distribution Map of Na.

$\mathrm{K}$ : The spatial analysis for two seasons i.e. pre-monsoon and post monsoon is given in Fig. 6 a \& b. During pre-monsoon seasons $\mathrm{K}$ is varying from 65.5 $\mathrm{mg} / \mathrm{l}$ to $0.04 \mathrm{mg} / \mathrm{l}$ and in post monsoon season it is varying from $196.3 \mathrm{mg} / \mathrm{l}$ to $0.11 \mathrm{mg} / \mathrm{l}$.

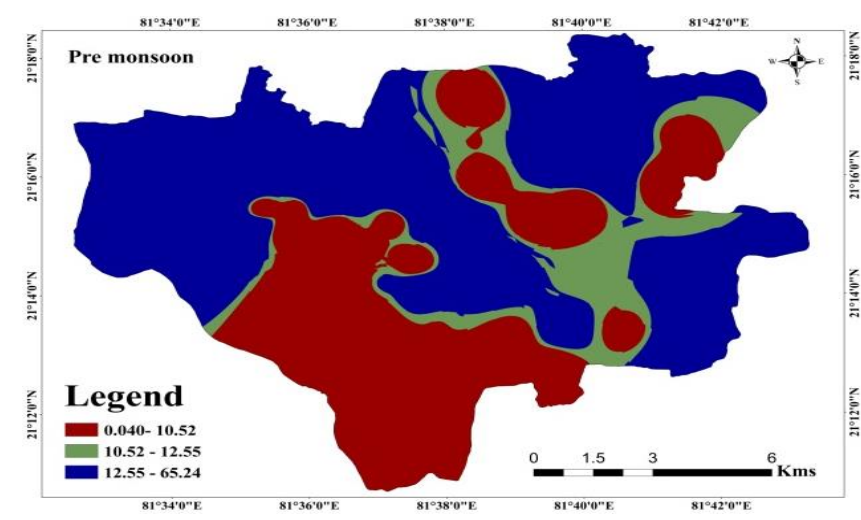

Fig. 6a: Spatial Distribution Map of K.

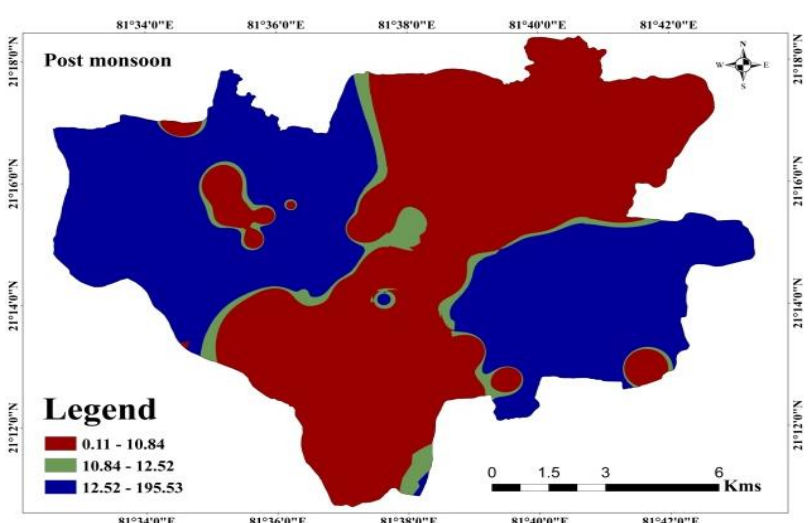

Fig. 6b: Spatial Distribution Map of K.

$\mathrm{HCO}_{3}$ : The spatial analysis for two seasons i.e. pre-monsoon and post monsoon is given in Fig.7a \& b. During pre-monsoon seasons $\mathrm{HCO}$ is varying from $528.39 \mathrm{mg} / \mathrm{l}$ to $112.2 \mathrm{mg} / \mathrm{l}$ and in post-monsoon season it is varying from $350.62 \mathrm{mg} / \mathrm{l}$ to $89.67 \mathrm{mg} / \mathrm{l}$.

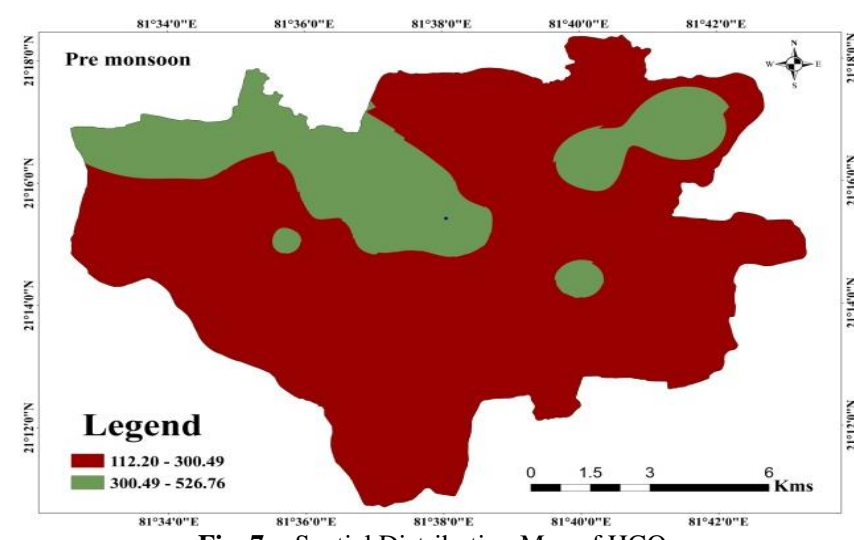

Fig. 7a: Spatial Distribution Map of $\mathrm{HCO}_{3}$.

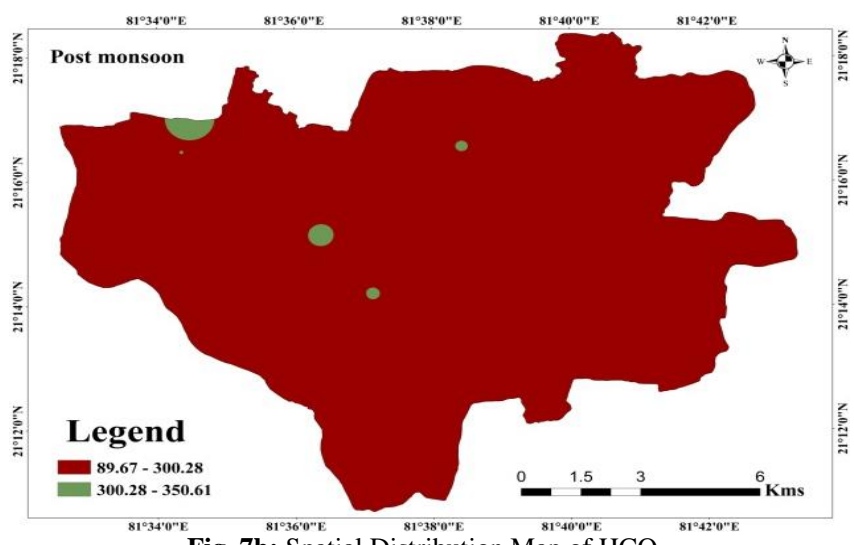

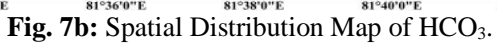

$\mathrm{NO}_{3}$ : The spatial analysis for two seasons i.e. pre-monsoon and post monsoon is given in Fig. 8 a \& b. During pre-monsoon seasons NO${ }_{3}$ is varying from $120.15 \mathrm{mg} / \mathrm{l}$ to $0.0002 \mathrm{mg} / \mathrm{l}$ and in post monsoon season it is varying from $150.26 \mathrm{mg} / \mathrm{l}$ to $5.2 \mathrm{mg} / \mathrm{l}$.

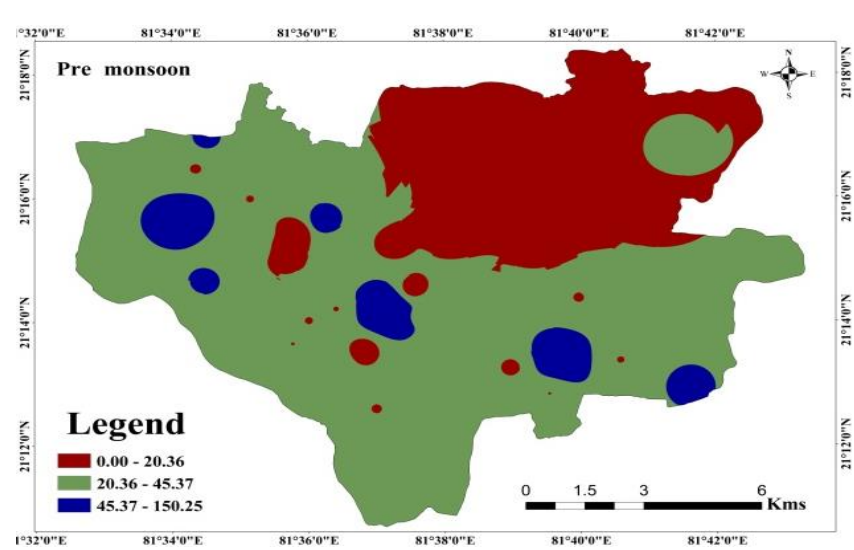

Fig. 8a: Spatial Distribution Map of $\mathrm{NO}_{3}$.

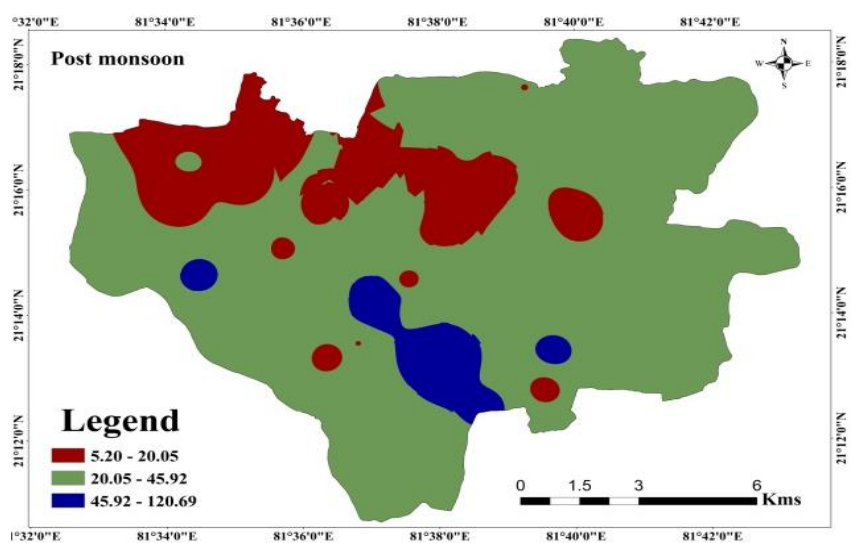

Fig. 8a: Spatial Distribution Map of $\mathrm{NO}_{3}$.

$\mathrm{SO}_{4}$ : The spatial analysis for two seasons i.e. pre-monsoon and post-monsoon is given in Fig.9 a \& b. During pre-monsoon seasons $\mathrm{SO}_{4}$ is varying from $220.14 \mathrm{mg} / 1$ to $2.00 \mathrm{mg} / \mathrm{l}$ and in post monsoon season it is varying from $280 \mathrm{mg} / 1$ to $1.20 \mathrm{mg} / \mathrm{l}$. 


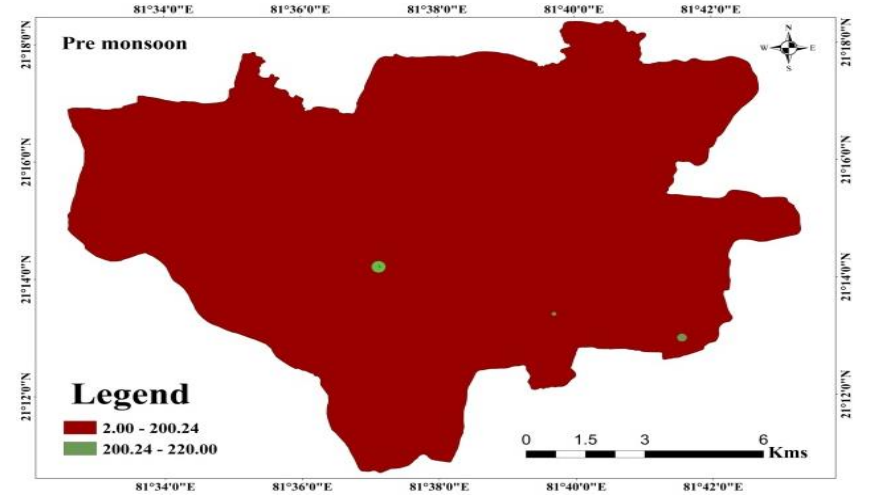

Fig. 9a: Spatial Distribution Map of $\mathrm{SO}_{4}$.

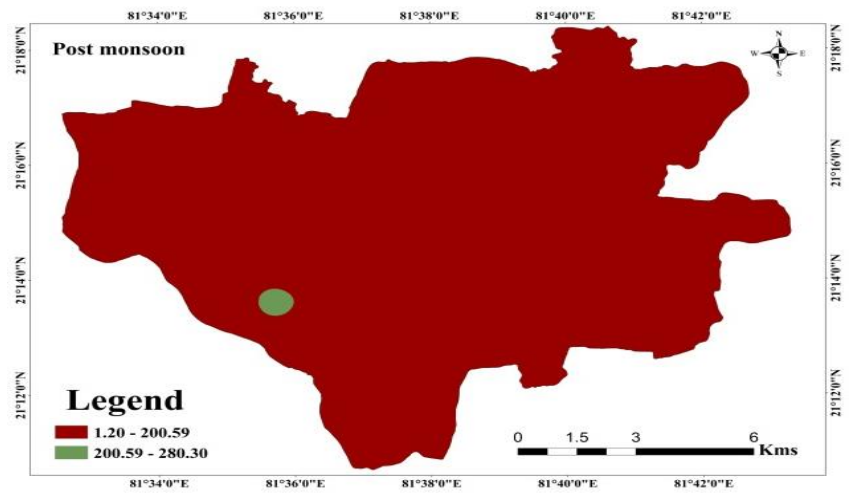

Fig. 9b: Spatial Distribution Map of $\mathrm{SO}_{4}$.

$\mathrm{Cl}$ : The spatial analysis for two periods i.e. pre-monsoon and post monsoon is given in Fig. 10 a $\&$ b. During pre-monsoon periods $\mathrm{Cl}$ is varying from 270 $\mathrm{mg} / \mathrm{l}$ to $40.002 \mathrm{mg} / \mathrm{l}$ and in post monsoon period it is varying from $260 \mathrm{mg} / \mathrm{l}$ to $50.002 \mathrm{mg} / \mathrm{l}$.

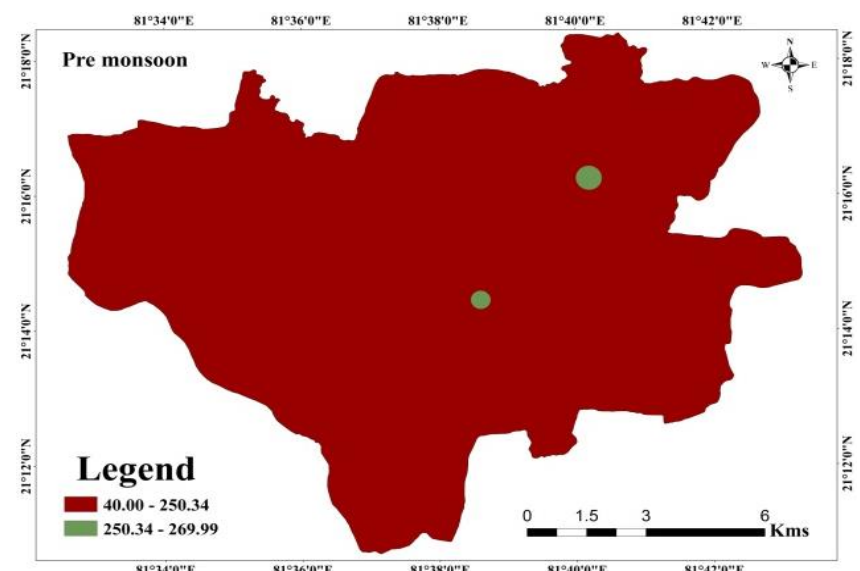

Fig. 10a: Spatial Distribution Map of $\mathrm{Cl}$.

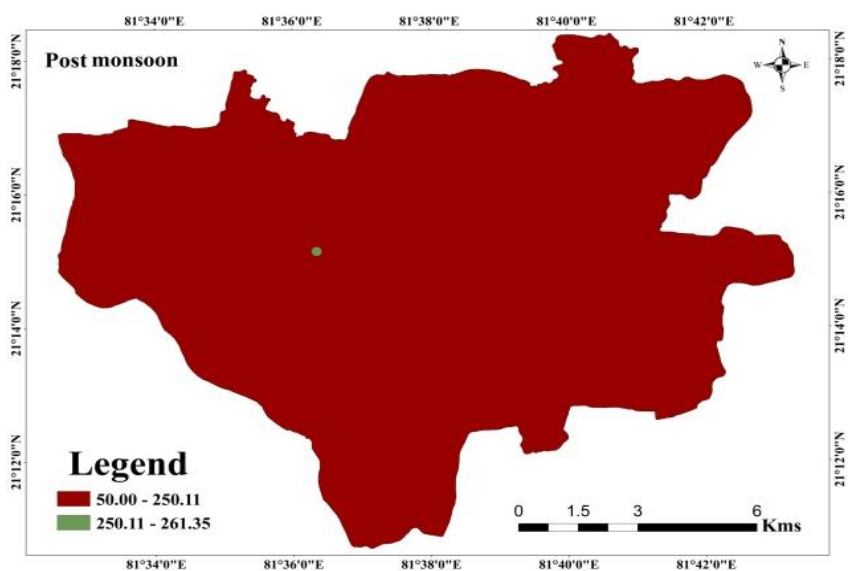

Fig. 10b: Spatial Distribution Map of $\mathrm{Cl}$.

Table 3: Showing Nitrate Concentration of Groundwater Sample

\begin{tabular}{|c|c|c|c|}
\hline Groundwater sample location code & Pre-monsoon & Post-monsoon & Location \\
\hline RK 1 & 20.2 & 37.8943 & Mangal Bazar, Gudhiyari \\
\hline RK 2 & 74.3 & 19.6608 & Kota colony, mangal bhavan \\
\hline RK 3 & 41 & 23.12 & Dumartalao \\
\hline RK 4 & 54.12 & 50.02 & Sarona \\
\hline RK 5 & 74.25 & 20.86643 & Tatibandh \\
\hline RK 6 & 24.901 & 19.02 & Jarwai \\
\hline RK 7 & 20 & 20.9098 & Hirapur \\
\hline RK 8 & 74.13 & 50 & Tenduwa \\
\hline RK 9 & 49.5776 & 22.15 & Kota \\
\hline RK 10 & 0 & 0 & Koteshwar (mandir) \\
\hline RK 11 & 21.25 & 25.3 & Saraswati nagar \\
\hline RK 12 & 10.16 & 12.5 & Amanaka \\
\hline RK 13 & 26.0843 & 20 & Danganiya \\
\hline RK 14 & 20.3 & 28.16 & Raipura \\
\hline RK 15 & 28.3 & 20 & Bhatagaon \\
\hline RK 16 & 45.35 & 35.6 & Mathpurena \\
\hline RK 17 & 32.18 & 40.5 & Santoshi nagar \\
\hline RK 18 & 20.25 & 21.5 & Lalpur \\
\hline RK 19 & 16.3 & 20 & Panchpedi naka \\
\hline RK 20 & 20 & 5.32142 & Telibandha \\
\hline RK 21 & 45.32 & 40.12 & Purani basti \\
\hline RK 22 & 150.26 & 120.15 & Shyam Mandir, samta colony \\
\hline RK 23 & 4.11 & 10.16 & Kushalpur talab \\
\hline RK 24 & 45.16 & 40.15 & Changhorbatha \\
\hline RK 25 & 20 & 26.2312 & DDU nagar \\
\hline RK 26 & 120.5 & 100 & New Rajendranagar \\
\hline RK 27 & 20 & 23.5 & Purena \\
\hline RK 28 & 20 & 25.12 & Paroti nagar \\
\hline RK 29 & 45.6 & 25 & Jail \\
\hline RK 30 & 12.5 & 9.9 & Fafadih \\
\hline RK 31 & 11.59 & 14.1 & WRS colony \\
\hline RK 32 & 11.23 & 14.63 & Bhanpuri \\
\hline RK 33 & 20 & 24.1 & Industrial Estate, Bhanpuri \\
\hline RK 34 & 16.32 & 20.53 & Mowa \\
\hline RK 35 & 25.3 & 30.25 & Saddu \\
\hline RK 36 & 11 & 5.2 & Ramkund \\
\hline RK 37 & 5.5 & 10.45 & Amapara \\
\hline RK 38 & 10.58 & 12.4 & Naharpara \\
\hline RK 39 & 15.5 & 20.1177 & Rajatalab \\
\hline RK 40 & 10.4 & 12.4 & Kachna \\
\hline RK 41 & 55.41 & 50.12 & Near energy park \\
\hline
\end{tabular}




\subsection{Groundwater quality}

In the study area, nine water quality parameters were analyzed for 41 groundwater samples. It is observed that in study area $\mathrm{Ca}, \mathrm{Mg}$, $\mathrm{K}$ and $\mathrm{NO}_{3}$ are above permissible limit and $\mathrm{SO}_{4}$ is above acceptable limit according to BIS standard. According to BIS standards $\mathrm{Ca}, \mathrm{K}$ and $\mathrm{Mg}$ have no direct influence on human health. It gives adverse effect on domestic use like encrustation on utensils. $\mathrm{SO}_{4}$ also have no major impact on human health but if its concentration is high in presence of $\mathrm{Na}$ and $\mathrm{Mg}$ can cause gastrointestinal irritation. $\mathrm{SO}_{4}$ is also a good indicator of $\mathrm{NO}_{3}$ concentration in groundwater. The Nitrate ion concentration in study area is found above $45 \mathrm{mg} / \mathrm{l}$ i.e. above permissible limit according to BIS standard. The value were compared with the BIS standard and found that in pre-monsoon period twelve sample have high concentration of Nitrate i.e. groundwater sample RK2 (74.3 mg/l), RK 4 (54.12 $\mathrm{mg} / \mathrm{l})$, RK 5 (74.25 mg/l), RK 8 (74.13 mg/l), RK 9 (49.57 mg/l), RK 16 (45.35 mg/l), RK 21 (45.32 mg/l), RK $22(150.26 \mathrm{mg} / \mathrm{l})$, RK 24 (45.16 mg/l) RK 26 (120 mg/l), RK 29 (45.6 mg/l) and RK $41(55.41 \mathrm{mg} / \mathrm{l})$ and in post- monsoon period five samples were found high concentration, i.e. RK 4 (54.02 mg/l), RK 8 (74.13 mg/l), RK 22 (120.15 mg/l RK 26 (120.5 mg/l), RK 41 (50.12 $\mathrm{mg} / \mathrm{l})$ and, which is shown in Fig.11 and Table 3. Concentration of Nitrate was found high during post-monsoon period as compare to a pre-monsoon period which indicating the leaching of sewage and fertilizer by rain water in the study area and in other condition high Nitrate concentration during pre-monsoon and low Nitrate concentration during post-monsoon period indication dilution of Nitrate ion by rain water (Wedland et al. 1994, Jhariya et al. 2012, Khandar 2013). Higher concentration of Nitrate in groundwater is due to anthropogenic activity mainly (Reddy et al. 2009, Jhariya et al. 2012, Khandar 2013). In study area nitrate concentration is mainly found in settlement area, which indicates that anthropogenic activity is main cause of high nitrate concentration in groundwater.

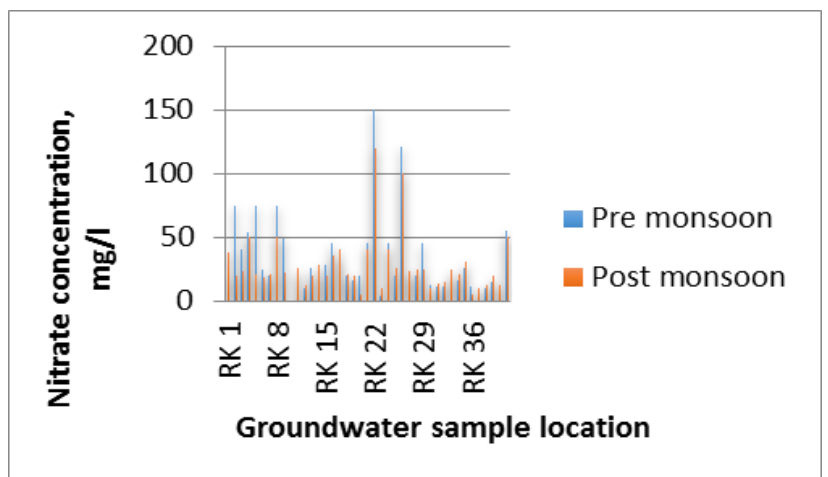

Fig. 11: Graph Showing Seasonal Variation in Nitrate Concentration.

\subsection{Source of nitrate pollution}

1) There are many sources in environment that contribute to the total nitrate content of natural waters, e.g. atmosphere, geological features, anthropogenic sources, atmospheric nitrogen fixation and soil nitrogen. It has been observed that in sandy soil with low water holding capacity and high permeability, movement of pollutants like nitrate is much quicker than in clayey soil (Jhariya et al. 2012, Khandar 2013).

2) Wastewater in the upper soil layer either from the cesspools or the disposal ponds could infiltrate to the groundwater aquifer. The absence of a sewage system encourages such types of contamination by nitrate (Jhariya et al. 2012, Khandar 2013). Thus, the level of nitrate in groundwater will continue to increase in the sources of contamination. These sources are more dangerous than the leaching ones, because of the daily use of water, which then recharges the aquifer.
3) Nitrate in groundwater can be derived from natural sources or from point sources, such as sewage disposal systems and livestock facilities causes pollution of surface water, ground water and wells through percolation. Waste materials are one of the anthropogenic sources of nitrate contamination of groundwater. Surface water runoff from fertilized farmland and animal feedlots is a major potential source of nitrate contamination. Septic tanks are another example of anthropogenic source nitrogen contamination of the groundwater (Jhariya et al. 2012, Khandar 2013).

\subsection{Mechanism of nitrate pollution in groundwater}

Nitrogenous materials are rare in the geological record; therefore, occurrence of nitrate in groundwater is normally of anthropogenic nature due to the contact of soil cover with contaminants like wastewater and nitrate fertilizers (Maila et al. 2004, Jhariya et al. 2012). The factors, which contribute to the aquifer contamination, comprise the partially-confined aquifer and the porous and permeable soil cover. Such hydrogeologic circumstances boost the groundwater contamination by allowing a direct contact between the contaminants and groundwater. Aquifers could be contaminated by point sources, leaching sources and biochemical transformation of organic nitrogen compounds acting as an encouraging mechanism enhancing the groundwater contamination, particularly in the point sources by the nitrification process (Maila et al. 2004, Jhariya et al. 2012).

\subsection{Effects of High Nitrate concentration}

1) Blue-baby Syndrome: Nitrates are especially poisonous to children less than six months of age. Children who ingest nitrate, suffer from a disease known as blue-baby syndrome (Jhariya et al. 2012, Khandar 2013). Cases of blue-baby syndrome usually occur mainly in shallow depth. Often these wells become contaminated when they are dug or bored and are located close to cultivated fields, feedlots, manure lagoons or septic tank. Methemoglobinemia is the condition in the blood which causes infant cyanosis, or blue-baby syndrome. Nitrate reacts with hemoglobin leading to formation of methaemoglobin in which iron is in ferric (III) state, greatly lessening the capacity of the blood to carry oxygen and causing chemical suffocation very young children are susceptible because fetal hemoglobin has a great affinity for nitrite than normal hemoglobin.

2) Stomach and Gastrointestinal Cancer: Nitrate itself is not cancer-causing, but instead acts as a "procarcinogen," i.e. it reacts with other chemicals (amines and amides) to form carcinogenic compounds (N-nitroso) compounds. The physiological studies provide strong support showing the association between nitrate contamination of drinking water and increased cancer rates. N-nitroso compounds have been associated with 15 different types of cancers, including tumors in the bladder, stomach, brain, esophagus, bone and skin, kidney, liver, lung, oral and nasal cavities, pancreas, peripheral nervous system, thyroid, trachea, acute myeleocytic leukemia and $\mathrm{T}$ and $\mathrm{B}$ cell lymphoma. More than one hundred of these N-nitroso compounds have been tested for carcinogenicity in animals and $75-80 \%$ of them have been found to be carcinogens (Jhariya et al. 2012, Khandar 2013).

\subsection{Prevention}

1) Proper sewage and drainage system.

2) Wells should be established during the height away from the septic tanks and fertilized area and well casing should be properly placed.

3) Water containing high nitrate levels can be safely used for another purpose like bathing, washing utensils and laundry. 
4) Heavy vehicles should not allow to run above the septic tank, and drain - pipes (Khandare 2013, Jhariya et al. 2012).

5) Reputable contractor should be hired to pump-out/clean septic tank every 2 to 3 years (Khandare 2013, Jhariya et al. 2012).

6) Social awareness like Residents of rural areas should have their wells tested, especially if pregnant women or infants are consumers of the well water. If the well is contaminated, other water source alternatives should be used and make sure that children should avoid consuming nitrate contaminate water.

\section{Conclusion}

Present study indicates that the parameters like $\mathrm{Ca}, \mathrm{Mg}, \mathrm{K}$ and $\mathrm{NO}_{3}$ are above permissible limit and $\mathrm{SO}_{4}$ is above the acceptable limit according to BIS standard. Nitrate ion concentration in study area is found above $45 \mathrm{mg} / \mathrm{l}$ i.e. above permissible limit according to BIS standard. Concentration of Nitrate ion was found high during post-monsoon period as compare to pre-monsoon period which indicating the leaching from sewage and fertilizer by rain water in the study area. In another condition, high Nitrate concentration during pre-monsoon and low Nitrate concentration during post-monsoon period indicating dilution of Nitrate ion by rain water in the study area. The sources of nitrate pollution in the study area are mainly due to anthropogenic activity.

\section{Acknowledgement}

Authors are highly thankful to the Chhattisgarh Council of Science and Technology (CGCOST) Raipur for providing lab facility to analyze groundwater quality. We wish to express our sincere thanks to all faculty members and Non-teaching staff of Department of Applied Geology, NIT Raipur for their help and encouragement to carried-out this work. It"s our pleasure to thanks those knowingly and unknowingly, who have helped make this work success.

\section{References}

[1] Abdulrahman, I. A., Al-Rehaili, A. M., Al-Zarah, A. I. and Khan M. A. (2010) Assessment of nitrate concentration in groundwater in Saudi Arabia. Environ Monit Assess. 161, 1-9, https://doi.org/10.1007/s10661-008-0722-7.

[2] Angelopoulos K., Spiliopoulos I.C., Theodorakopoulou A. A. M., Kouvelas A (2009) Groundwater nitrate pollution in northern part of Achaia Prefecture. Science Direct. 248,852-858. https://doi.org/10.1016/j.desal.2008.11.007.

[3] APHA (1995) Standard methods for the examination of water and wastewater, 19th edn. American Public Health Association, Washington, $1-467$.

[4] BIS (1991) (Bureau of Indian Standards) 10500 Indian Standard drinking water specification, 1 st rev, 1-8.

[5] Elmidaoui, A., Elhannouni, M. A., Menkouchi, S., Chay, L., Elabbassi, H., Hafsi, M., et al. (2001). Pollution of nitrate in Moroccan groundwater: Removal by electrodialysis. Desalination, 136, 325332. https://doi.org/10.1016/S0011-9164(01)00195-3.

[6] Fan, A. M., Willhite, C. C., \& Book, S. A. (1987). Evaluation of the nitrate drinking water standard with reference to infant methemoglobinemia and potential reproductive toxicity. Regulatory Toxicology and Pharmacology, 7, 135-148.

[7] Fan, A. M., \& Steinberg, V. E. (1996). Health implications of nitrate and nitrite in drinking water: An update on methemoglobinemia occurrence and reproductive and developmental toxicity. Regulatory Toxicology and Pharmacology, 23, 35-43. https://doi.org/10.1006/rtph.1996.0006.

[8] Hem, J. D. (1985). Study and interpretation of the chemical characteristics of natural water. U.S. Geological Survey Water-Supply Paper, 2254, 1-263.

[9] Hudak, P. F. (2000). Regional trends in nitrate content of Texas groundwater. Journal of Hydrology (Amsterdam), 228, 37-47.
[10] Imran A. D, Mithas A. D., Sankar K. (2009) Nitrate contamination in groundwater of Sopore town and its environs, Kashmir, India. Arab J Geosci, 3, 267-272.

[11] Imran A. D. (2010) "Assessment of nitrate contamination of Lidder catchment Kashmir, India", Arabian Journal of Geosciences.

[12] Jhariya D.C., Shandilya A. K. and Dewangan R. (2012) Nitrate Pollution in the Groundwater around Sagar Town, Madhya Pradesh, India. International Conference on Chemical, Ecology and Environmental Sciences (ICEES'2012) Bangkok.

[13] Khandar, H. W. (2013) Scenario of Nitrate contamination in Groundwater: Its causes and Prevention. International Journal of ChemTech Research CODEN (USA): IJCRGG ISSN: 0974-4290, 5:4, 1921-1926.

[14] Mail, Y. A., El-Nahal I., M.R. (2004) Seasonal variations and mechanismsof groundwater nitrate pollution in the Gaza Strip AlAgha. Environmental Geology, 47, 84-90. https://doi.org/10.1007/s00254-004-1136-7.

[15] Nolan, B. T. (2001). Relating nitrogen sources and aquifer susceptibility to nitrate in shallow groundwater of the United States. Groundwater, 39, 290-299. https://doi.org/10.1111/j.17456584.2001.tb02311.x.

[16] Reddy A. G. S., Kumar K. N., Rao D. S., \& Rao S. S. (2009) Assessment of nitrate contamination due to groundwater pollution in north eastern part of Anantapur District, A.P. India. Environ Monit Assess.148:463-476. https://doi.org/10.1007/s10661-008-0176-y.

[17] Spalding, R. F., \& Exner, M. E. (1993). Occurrence of nitrate in groundwater-a review. Journal of Environ- mental Quality, 22, 392-402. https://doi.org/10.2134/jeq1993.00472425002200030002x.

[18] Wendland F., Albert H., Bach M., Schmidt R. (1994) Potential nitrate pollution of groundwater in Germany: A supraregional differentiated model. Environmental Geology 24, 1-6.

[19] WHO (2011) WHO Guidelines for Drinking-water Quality, fourthed. World Health Organization. 